\title{
PENGARUH APLIKASI RAGAM BAHAN ORGANIK DAN FMA TERHADAP PERTUMBUHAN DAN HASIL TANAMAN CABAI (Capsicum annum L.) VARIETAS LANDUNG PADA TANAH PASCA GALIAN C
}

\section{EFFECT OF ORGANIC MATTER AND AMF ON GROWTH AND YIELD OF CHILI PLANTS (Capsicum annum L.) LANDUNG VARIERTY ON POST-EXCAVATION SOIL C}

\author{
Muhamad Fajar Ramadhan, Cecep Hidayat, Sofiya Hasani \\ Jurusan Agroteknologi UIN Sunan Gunung Djati Bandung \\ Korespondensi : cephidayat62@uinsgd.ac.id
}

Diterima 30 November 2015 / Disetujui 23 Desember 2015

\begin{abstract}
ABSTRAK
Penelitian yang bertujuan untuk mengetahui pengaruh bahan organik (kompos gamal, dan asam humat) serta FMA (Glomus sp. + Gigaspora sp.+ Aclauspora sp) terhadap pertumbuhan serta hasil tanaman cabai pada tanah pasca galian $C$ telah dilaksanakan di Gapoktan Simpay Tampomas, Sumedang sejak bulan Februari sampai dengan Juli 2014. Metode yang digunakan merupakan metode eksperimental berupa Rancangan Acak Kelompok (RAK), dengan 8 perlakuan dan 4 kali ulang: $a 0=$ kontrol, a1 $=$ kompos gamal $5 \mathrm{t} \mathrm{ha}^{-1}$, a2 $=$ kompos gamal $10 \mathrm{t} \mathrm{ha}^{-1}$, a3 $=$ aplikasi FMA, a4 = asam humat, a5 $=$ kompos gamal $5 \mathrm{t} \mathrm{ha}^{-1}+\mathrm{FMA}$ , a6 = kompos gamal $10 \mathrm{t} \mathrm{ha}^{-1}+\mathrm{FMA}$, dan a7 = aplikasi asam humat + FMA. Pengujian lanjut dilakukan dengan Duncan Multiple Range Test (DMRT). Hasil penelitian menunjukkan bahwa aplikasi kompos gamal, asam humat, dan FMA tidak berpengaruh nyata terhadap diameter batang dan bobot segar buah, tetapi berbeda nyata terhadap tinggi tanaman. Pengaplikasian bahan organik hingga $10 \mathrm{t} \mathrm{ha}^{-1}$, asam humat, dan FMA belum berpengaruh nyata terhadap perbaikan kesuburan tanah pasca galian $\mathrm{C}$ (tambang pasir), karena kondisi tanah pasca galian $\mathrm{C}$ yang didominasi $75 \%$ pasir dan $50 \%$ batuan.
\end{abstract}

Kata Kunci : Bahan Organik, Cabai, Fungi Mikoriza Arbuskula, Tanah Pasca Galian C

\begin{abstract}
The study which aimed to determine the effect of organic matter (gliricidia compost, and humic acid) also AMF (Glomus sp. + Gigaspora sp. + Aclauspora sp.) on growth and yield of chili plants on post-excavation soil $C$ had been held in Gapoktan Simpay Tampomas, Sumedang from February to July 2014. The method was an experimental method a randomized block design (RBD), with 8 treatments and repeated 4 times: $\mathrm{a} 0=$ control, $\mathrm{a} 1=$ gliricidia compost $5 \mathrm{t}$ $\mathrm{ha}^{-1}$, a2 = gliricidia compost $10 \mathrm{t} \mathrm{ha}^{-1}$, a3 = AMF, a4 = humic acid, a5 = gliricidia compost 5 tons $\mathrm{ha}^{-1}+\mathrm{AMF}, \mathrm{a} 6=$ gliricidia compost 10 tons $\mathrm{ha}^{-1}+\mathrm{AMF}$, and a7 = humic acid + AMF. Further testing was done by Duncan Multiple Range Test (DMRT). The results showed that the application of gliricidia compost, humic acid, and AMF did not significantly affect stem diameter, and fresh weight of fruit, but significant on stem height. Application of organic
\end{abstract}


matter up to 10 tons $h^{-1}$, humic acid, and AMF had not significantly affect fertility improvement of post-excavation soil C (sand mining), because the soil C dominated by $75 \%$ sand and $50 \%$ rock.

Key words : Arbuscular mycorrhizal fungi, chilli, organic matter, post-excavation soil C.

\section{PENDAHULUAN}

Di Kecamatan Cimalaka, Kabupaten Sumedang sekitar 252,37 ha merupakan penambangan pasir yang ada, dan sebagian besar sudah terbengkalai hingga menjadi hamparan padang pasir (Kabar UKM, 2012). Kesuburan tanah pasca galian C (galian pasir) dari segi sifat fisika, kimia, dan biologi termasuk kategori rendah, namun memiliki potensi kandungan P-Total dan Ptersedia yang tinggi (Utami, 2009). Pada tahun 1983 hingga sekarang petani lokal Uha Juhari membeli lahan pasca galian $C$ seluas 3 ha dan mengolahnya, sampai sekarang pola penanaman yang dilakukan di lapangan sebagai langkah reklamasi ialah integrasi antara gamal, rumput gajah, kaliandra sebagai pakan ternak dan tanaman buah naga sebagai komoditas yang dibudidayakan.

Dalam penelitian ini dicoba penanaman tanaman cabai (Capsicum Annum L.), yang memiliki nilai ekonomis yang tinggi. Untuk mendukung budidaya tanaman cabai tersebut perlu dimulai dengan pemulihan kesuburan tanah pasca galian $\mathrm{C}$ melalui penambahan bahan organik dan pemanfaatan Fungi Mikoriza Arbuskula (FMA).

Bahan organik yang digunakan pada penelitian ini adalah kompos tanaman gamal (Gliricidia sepium) dan asam humat. Daun gamal jika dijadikan pupuk organik mempunyai kandungan nitrogen tinggi (Jusuf, 2007). Ibrahim (2001) memperlihatkan dari daun gamal dapat diperoleh sebesar 3,15\% N, 0,22 \% P, 2,65 $\% \mathrm{~K}, 1,35 \% \mathrm{Ca}$ dan 0,41 \% Mg. Asam humat memiliki struktur yang terdiri dari campuran senyawa organik alifatik dan aromatik, (gugus aktif asam karboksilat dan quinoid) sehingga memiliki kemampuan untuk menstimulasi dan mengaktifkan proses biologi dan fisiologi pada organisme hidup di dalam tanah sehinga dikenal sebagai pembenah tanah (Hermanto, 2012).

FMA merupakan suatu bentuk asosiasi antara jamur dengan akar tumbuhan tingkat tinggi, dimana FMA menginfeksi akar tanaman kemudian membantu penyerapan hara dari tanah untuk pertumbuhan dan perkembangan tanaman. Tanaman yang bermikoriza biasanya tumbuh lebih baik dari pada yang tidak bermikoriza, dapat meningkatkan penyerapan unsur hara makro dan beberapa unsur hara mikro. Selain itu akar tanaman yang bermikoriza dapat menyerap unsur hara dalam bentuk terikat dan tidak tersedia untuk tanaman (Rahayu dan Akbar, 2003).

FMA dan bahan organik sama dapat memperbaiki sifat fisik tanah, FMA dapat membentuk hifa eksternal yang mengikat partikel tanah sehingga stabilitas agregat tanah dan pori tanah menjadi lebih baik. Sedangkan kompos daun gamal maupun asam humat sebagai bahan organik dapat meningkatkan kapasitas menahan air karena bahan organik mampu menahan air dua kali dari bobot tubuhnya. Dari segi kimia tanah FMA dapat memenuhi 
ketersediaan unsur hara seperti $\mathrm{P}, \mathrm{Mg}, \mathrm{K}, \mathrm{Fe}$ dan $\mathrm{Mn}$, sementara kompos daun gamal menyumbang hara $\mathrm{C}$ dan $\mathrm{N}$. Sedangkan dari segi biologi tanah FMA berinteraksi dengan mikroorganisme lain sebagai dekomposer pada tanah sementara kompos daun gamal sebagai bahan organik memberikan $C$ sebagai sumber makanan dan menjadi tempat bagi FMA dan mikoorganisme lainnya untuk hidup dan berkembang (Nurbaity, 2009).

Aplikasi FMA dan kompos merupakan kolaborasi yang baik untuk meningkatkan kembali kesuburan tanah bekas galian pasir dengan kondisi tanah yang lebih baik dari segi fisik tanah (agregat, pori, kapasitas menahan air), kimia tanah (tersedianya $\mathrm{N}$, $\mathrm{P}, \mathrm{K}, \mathrm{Mg}, \mathrm{Fe}$, dan $\mathrm{Mn}$ ), serta biologi tanah (mikroba) maka tentu akan meningkatkan pertumbuhan dan hasil tanaman cabai.

Dari pernyataan di atas dapat disimpulkan bahwa kompos daun gamal sebagai bahan organik dapat berinteraksi positif dengan FMA sebagai sumber karbon yang akan dipergunakan untuk memperbaiki kesuburan tanah bekas galian pasir baik dari segi fisik, kimia, dan biologi yang ditandai dengan pertumbuhan tanaman cabai yang baik.

\section{BAHAN DAN METODE}

Penelitian dilaksanakan pada Januari-Juli 2014 di Gapoktan Simpay Tampomas, Dusun Golempang, Desa Cibeureum Wetan, Kecamatan Cimalaka, Kabupaten Sumedang dengan ketinggian 600-800 mdpl, curah hujan $2.622 \mathrm{~mm} /$ tahun (Profil Desa Cibeureum Wetan, 2014).

Bahan yang digunakan dalam penelitian ini adalah sebagai berikut : Tanah bekas galian C, FMA (Glomus sp., Gigaspora sp.,
Aclauspora sp.), kompos daun gamal, benih cabai varietas landung, asam humat $30 \%$, urea, TSP, KCL.

Penelitian menggunakan Rancangan Acak Kelompok (RAK) satu faktor dengan empat kali ulangan. Perlakuan yang digunakan adalah jenis dan dosis bahan organik serta aplikasi FMA, yaitu:

a0 : Tanpa perlakuan

a1 : 5 t ha $^{-1}$ kompos gamal

a2 : $10 \mathrm{t} \mathrm{ha}^{-1}$ kompos gamal

a3 : 5 g FMA ((Glomus sp. + Gigaspora sp.+ Aclauspora sp.)

a4 : $2 \mathrm{ml} \mathrm{L}^{-1}$ asam humat

a5 : $5 \mathrm{t} \mathrm{ha}^{-1}$ kompos gamal + FMA

a6 : 10 t ha $^{-1}$ kompos gamal + FMA

a7 : $2 \mathrm{ml} \mathrm{L}^{-1}$ asam humat + FMA

\section{HASIL DAN PEMBAHASAN}

Analisis tanah awal tanah pasca galian $\mathrm{C}$ menunjukan $\mathrm{pH}$ aktual netral dengan nilai 6,85 . Kandungan C-organik rendah dengan nilai $0,35 \%$, kandungan $\mathrm{N}$-total rendah dengan nilai $0,10 \%$, kandungan P-total dan P-tersedia yang tinggi dimana P-totalnya bernilai $156,44 \mathrm{mg} \cdot 100 \mathrm{~g}^{-1}$ dan P-tersedia yang bernilai $15,19 \mathrm{ppm}$ P.

Dilihat dari sifat fisik tanah yaitu tekstur, tanah pasca galian C Desa Cibeureum Wetan memiliki kandungan 75\% pasir, 12\% debu, dan $13 \%$ liat yang termasuk kriteria lempung berpasir.

\section{Diameter batang}

Setelah dilakukan analisis ragam menggunakan DSTAAT hasil diameter batang pada 2, 4, 6 dan 8 MST adalah tidak berbeda nyata. Hasil tertinggi pada 2, 4, 6, dan 8 MST untuk parameter diameter batang adalah perlakuan a6 (aplikasi gamal $10 \mathrm{t} \mathrm{ha}^{-1}+$ FMA) ( Tabel 1). 
Tabel 1. Pengaruh aplikasi kompos gamal, FMA, dan asam humat terhadap diameter batang 2, 4, 6 dan 8 MST

\begin{tabular}{ccccc}
\hline \multirow{2}{*}{ Perlakuan } & \multicolumn{5}{c}{$\begin{array}{c}\text { Nilai Rata-Rata Diameter Batang }(\mathrm{mm}) \\
\text { Umur Tanaman MST }\end{array}$} \\
\hline & 2 & 4 & 6 & 8 \\
\hline a0 & $3,00 \mathrm{a}$ & $3,23 \mathrm{a}$ & $4,13 \mathrm{a}$ & $5,25 \mathrm{a}$ \\
a1 & $3,20 \mathrm{a}$ & $3,68 \mathrm{a}$ & $5,20 \mathrm{a}$ & $5,75 \mathrm{a}$ \\
a2 & $3,28 \mathrm{a}$ & $3,82 \mathrm{a}$ & $5,28 \mathrm{a}$ & $7,38 \mathrm{a}$ \\
a3 & $2,78 \mathrm{a}$ & $3,12 \mathrm{a}$ & $4,43 \mathrm{a}$ & $6,00 \mathrm{a}$ \\
a4 & $2,90 \mathrm{a}$ & $3,70 \mathrm{a}$ & $5,20 \mathrm{a}$ & $6,50 \mathrm{a}$ \\
a5 & $3,18 \mathrm{a}$ & $3,55 \mathrm{a}$ & $4,80 \mathrm{a}$ & $6,13 \mathrm{a}$ \\
a6 & $3,50 \mathrm{a}$ & $4,40 \mathrm{a}$ & $6,70 \mathrm{a}$ & $7,68 \mathrm{a}$ \\
a7 & $3,35 \mathrm{a}$ & $3,75 \mathrm{a}$ & $5,25 \mathrm{a}$ & $6,75 \mathrm{a}$ \\
\hline
\end{tabular}

Keterangan : Angka-angka yang diikuti oleh notasi huruf yang sama pada kolom yang sama menunjukkan beda tidak nyata berdasarkan Uji lanjut Duncan pada taraf $5 \%$

Dari parameter diameter batang perlakuan A6 (gamal $10 \mathrm{t} \mathrm{ha}^{-1}+\mathrm{FMA}$ ) adalah perlakuan yang memiliki nilai ratarata paling tinggi untuk setiap waktu pengamatan $(2,4,6$, dan 8 MST) dibandingkan perlakuan lainnya walaupun tak menunjukan hasil yang berbeda nyata setelah dilakukan uji parametrik.

Kandungan $\mathrm{N}$ yang rendah pada tanah pasca galian $\mathrm{C}$ menyebabkan pertumbuhan diameter batang tanaman cabai menjadi tidak berbeda nyata, Fungsi $\mathrm{N}$ bagi tanaman pada umumnya diperlukan untuk pembentukan atau pertumbuhan bagianbagian vegetatif tanaman dan berperan penting dalam pembentukan klorofil untuk meningkatkan proses fotosintesis yang ada pada gilirannya akan meningkatkan pertumbuhan tanaman seperti batang, akar dan daun (Mahdianoor, 2011).

Tidak seimbangannya unsur hara pada tanah pasca galian C menjadikan pertumbuhan tanaman tidak optimal, kandungan P-total yang tinggi namun tidak didukung dengan unsur hara lain seperti $\mathrm{N}$ dan C-organik menyebabkan pertumbuhan tanaman tidak optimal.

Aplikasi bahan organik pada perlakuan dinilai kurang untuk pertumbuhan diameter batang tanaman cabai di tanah pasca galian C. Peningkatan dosis pemupukan bahan organik dan pemupukan $\mathrm{N}$ diperlukan agar pertumbuhan tanaman cabai diantaranya parameter diameter batang yang berfungsi sebagai tempat mengalirnya hara akan lebih baik lagi, dengan ditandai hasil analisis ragam yang berbeda nyata.

\section{Tinggi tanaman}

Setelah dilakukan analisis ragam tinggi tanaman cabai 2 MST adalah tidak berbeda nyata. Namun pada 4, 6, dan 8 MST menunjukan hasil yang berbeda nyata dan sangat berbeda nyata. Setelah dilakukan uji lanjut duncan, pada 2 MST perlakuan tidak berbeda nyata, tetapi pada 4, 6, dan 8 MST perlakuan berbeda nyata secara mandiri. Perlakuan a6 memiliki nilai rata-rata yang paling tinggi pada 4, 6, dan 8 MST (Tabel 5).

Pada 2 MST tanaman masih dalam fase vegetatif awal dan masih mengalami proses 
adaptasi dengan lingkungan sehingga aplikasi kompos gamal, asam humat, dan
FMA belum berpengaruh terhadap tanaman cabai (Tabel 2).

Tabel 2. Pengaruh aplikasi kompos gamal, FMA, dan asam humat terhadap tinggi tanaman 2, 4, 6 dan 8 MST

\begin{tabular}{ccccc}
\hline Perlakuan & \multicolumn{5}{c}{$\begin{array}{c}\text { Nilai Rata-Rata tinggi tanaman }(\mathrm{cm}) \\
\text { Umur Tanaman MST }\end{array}$} \\
\hline & 2 & 4 & 6 & 8 \\
\hline a0 & $12,00 \mathrm{a}$ & $13,25 \mathrm{a}$ & $18,50 \mathrm{a}$ & $23,00 \mathrm{a}$ \\
a1 & $13,75 \mathrm{a}$ & $19,50 \mathrm{c}$ & $31,00 \mathrm{~d}$ & $44,00 \mathrm{e}$ \\
a2 & $13,50 \mathrm{a}$ & $20,00 \mathrm{~d}$ & $33,75 \mathrm{f}$ & $45,00 \mathrm{f}$ \\
a3 & $12,75 \mathrm{a}$ & $15,75 \mathrm{~b}$ & $25,75 \mathrm{~b}$ & $38,00 \mathrm{~b}$ \\
a4 & $13,25 \mathrm{a}$ & $19,50 \mathrm{c}$ & $36,25 \mathrm{~g}$ & $52,00 \mathrm{~g}$ \\
a5 & $15,75 \mathrm{a}$ & $20,00 \mathrm{~d}$ & $28,25 \mathrm{c}$ & $40,50 \mathrm{c}$ \\
a6 & $14,50 \mathrm{a}$ & $25,00 \mathrm{e}$ & $42,00 \mathrm{~h}$ & $53,50 \mathrm{~h}$ \\
a7 & $14,00 \mathrm{a}$ & $20,00 \mathrm{~d}$ & $33,00 \mathrm{e}$ & $43,50 \mathrm{~d}$ \\
\hline
\end{tabular}

Keterangan : Angka-angka yang diikuti oleh notasi huruf yang sama pada kolom yang sama menunjukkan beda tidak nyata berdasarkan Uji lanjut Duncan pada taraf $5 \%$

Pertumbuhan tanaman dipengaruhi oleh ketersediaan unsur hara yang dibutuhkan dalam jumlah yang cukup, yang dapat diperoleh dari penambahan unsur hara dari luar (Mahdianoor, 2011).

Perlakuan a6 aplikasi kompos gamal $10 \mathrm{t}$ $\mathrm{ha}^{-1}+$ FMA menghasilkan sangat berbeda nyata setelah dilakukan uji parametrik, karena bahan organik memberikan konstribusi yang nyata terhadap KTK tanah (Atmojo, 2003), kemudian kandungan N, K, dan Ca yang yang cukup tinggi pada gamal yaitu 2,65 \%, 1,35\%, dan 3,5\% (Ibrahim, 2002) sehingga berpengaruh nyata terhadap tinggi tanaman. Selain itu juga adanya FMA dapat membantu meningkatkan serapan hara pada tanaman dimana FMA membentuk simbiosis mutualisme dengan tanaman inangnya sehingga dengan bantuan hifa dapat menyerap unsur hara yang tidak bisa diserap lewat perakaran tanaman (Simanungkalit, 2006).
Bahan Organik berinteraksi positif dengan FMA pada lahan-lahan bermasalah seperti tanah cekaman kekeringan (Nurbaity, 2009), demikian pula yang terjadi pada tanah pasca galian $\mathrm{C}$ yang dijadikan media penelitian adalah tanah yang bermasalah dan miskin unsur hara. Kompos gamal sebagai bahan organik berfungsi sebagai penyedia unsur hara sekaligus tempat penyedia $C$ dan tempat pertumbuhan hifa eksternal bagi FMA, sebaliknya FMA dapat mendekomposisi bahan organik sehingga dapat menyerap unsur hara yang dibutuhkan tanaman, kemudian digunakan tanaman untuk tumbuh dan berkembang (Brundrett, 1994), sehingga hasil yang diperoleh berbeda nyata pada tinggi tanaman cabai.

\section{Bobot segar buah}

Setelah dilakukan analisis ragam, perlakuan menunjukan hasil tak berbeda nyata terhadap parameter bobot buah segar. Nilai tertinggi diperoleh dari 
perlakuan a6 (aplikasi kompos gamal $10 \mathrm{t}$ $\mathrm{ha}^{-1}+\mathrm{FMA}$ ) dan perlakuan a3 (aplikasi kompos gamal $10 \mathrm{t} \mathrm{ha}^{-1}$ ) (Tabel 3 ).

Tabel 3. Pengaruh aplikasi kompos gamal, FMA, dan asam humat terhadap bobot segar buah tanaman

\begin{tabular}{cc}
\hline Perlakuan & $\begin{array}{c}\text { Bobot Buah } \\
(\mathrm{g})\end{array}$ \\
\hline a0 & $20,53 \mathrm{a}$ \\
a1 & $79,24 \mathrm{a}$ \\
a2 & $135,05 \mathrm{a}$ \\
a3 & $82,41 \mathrm{a}$ \\
a4 & $92,82 \mathrm{a}$ \\
a5 & $66,58 \mathrm{a}$ \\
a6 & $133,36 \mathrm{a}$ \\
a7 & 90,65 a \\
\hline Keterangan : & Angka-angka yang diikuti oleh \\
& notasi huruf yang sama pada \\
& kolom yang sama menunjukkan \\
& beda tidak nyata berdasarkan \\
& Uji lanjut Duncan pada taraf 5\%
\end{tabular}

Bobot buah yang didapat pada penelitian ini rata-rata nilai terbaiknya adalah $135.05 \mathrm{~g}$ per tanaman, sangat berbeda produksi cabai besar nasional pada tahun 2010 yang menyatak 5,6 t ha ${ }^{-1}$ (BPS, 2011) atau sekitar 2,35 kg per tanaman. Koefisien variasi yang tinggi hingga $44 \%$ dipengaruhi oleh 5 tanaman yang tidak menghasilkan buah, empat diantaranya pada ulangan 4. Pada ulangan 4 letak tanaman berdekatan dengan tanaman buah naga sehingga ternaungi yang menyebabkan kurangnya penyinaran tanaman cabai. Penyinaran yang cukup sangat berpengaruh terhadap tanaman, karena fotosintesis pada klorofil terjadi dengan bantuan sinar matahari (Harjadi, 1991).

Hasil suatu tanaman salah satunya sangat dipengaruhi oleh media tumbuh (tanah) tanaman itu sendiri. Kondisi tanah pasca galian $\mathrm{C}$ dengan kandungan $75 \%$ pasir dan $50 \%$ batuan mengakibatkan rendahnya C-organik dan $\mathrm{N}$-total tanah. $\mathrm{Hal}$ ini berpengaruh terhadap bobot segar buah cabai karena unsur hara pada tanah dapat berpengaruh terhadap metabolisme tanaman. Jika suatu tanaman kekurangan unsur hara, maka metabolisme tanaman akan terganggu sehingga berdampak terhadap pertumbuhan dan perkembangan tanaman, dan jika memasuki fase generatif akan berpengaruh pada kuantitas dan kualitas buah.

Kandungan C-organik tanah pasca galian $C$ yang rendah, meskipun telah dilakukan aplikasi kompos gamal 10 ton $\mathrm{ha}^{-1}$. Kandungan C-organiknya masih kurang dari $1,5 \%$ (Tabel 1) masih kurang untuk mencapai kondisi tanah normal yaitu sekitar $2 \%$ sehingga berpengaruh terhadap ketersedian hara yang diserap tanaman, karena bahan organik dapat menyediakan unsur hara relatif lengkap walaupun dengan jumlah yang sedikit untuk tanaman dengan proses mineralisasi (Atmojo, 2003) sehingga pada fase generatif kualitas buah akan terganggu.

Selain itu juga, kandungan C-organik yang rendah berbanding lurus dengan kandungan N-total tanah (Cookson, 2002). Meskipun unsur $\mathrm{N}$ pada fase generatif dibutuhkan tak sebanyak saat fase vegetatif, tetapi unsur $\mathrm{N}$ masih sangat berperan penting dalam pembentukan protein dan klorofil yang berfungsi untuk menyerap cahaya matahari serta sebagai tempat berlangsungnya proses fotosintesis (Harjadi, 1991), dimana hasil fotosintesi berupa karbohidrat salah satunya disimpan sebagai cadangan makanan tanamn dalam bentuk buah. 
Aplikasi kompos gamal, asam humat, dan FMA belum menghasilkan pengaruh yang berbeda nyata terhadap parameter bobot segar buah. Peningkatan dosis bahan organik dan pemberian secara kontinyu dirasa diperlukan untuk memperbaiki kesuburan tanah pasca galian $\mathrm{C}$ dan hasil tanaman cabai.

\section{SIMPULAN}

Berdasarkan hasil penelitian dapat ditarik kesimpulan bahwa aplikasi kompos gamal hingga $10 \mathrm{t} \mathrm{ha}^{-1}$, asam humat $2 \mathrm{ml} \mathrm{L}^{-1}$ dan FMA $10 \mathrm{~g}$ per tanaman belum berpengaruh nyata pada pertumbuhan diameter batang dan hasil bobot segar buah tanaman namun aplikasi kompos gamal $10 \mathrm{t}$ $\mathrm{ha}^{-1}+$ FMA $10 \mathrm{~g}$ per tanaman dapat meningkatkan pertumbuhan tinggi tanaman cabai.

\section{DAFTAR PUSTAKA}

Atmojo, S. W. 2003. Peranan Bahan Organik Terhadap Kesuburan Tanah Dan Upaya Pengelolaannya. Pidato Pengukuhan Guru Besar Ilmu Kesuburan Tanah Fakultas Pertanian Universitas Sebelas Maret. Surakarta.

Badan Pusat Statistik. 2011. Luas Panen Produksi dan Produktivitas Tanaman Cabai 2010. Badan Pusat Statistik Republik Indonesia. Jakarta.

Brundrett, M., N. Bougher, B. Dell, T. Grave and N. Malajezuk. 1996. Working with Mycorrizha in Forestry and Agriculture. Australian Centre for International Agricultural Research (ACIAR). Canbera.

Cookson, W. R, I. S. Cornforth and J.S. Rowarth. 2002. Winter soil temperatur $(2-15$ oC) effect on nitrogen transformations in clover green manure amandend and unamandend soils : a laboratory and field study. Soil Biol. Biochem. 34: 1401-1415.

Harjadi. 1991. Pengantar Agronomi. PT Gramedia. Jakarta.

Hermanto, D. dkk. 2012. Pengaruh Asam Humat Sebagai Pelengkap Pupuk Terhadap Ketersediaan dan Pengambilan Nutrien Pada Tanaman Jagung Di Lahan Kering Kec. Bayan Kabupaten Lombok Utarantb. Lembaga Penelitian Universitas Mataram. Mataram.

Ibrahim, B. 2001. Integrasi Jenis Tanaman Pohon Leguminosa Dalam Sistem Budidaya Pangan Lahan Kering dan Pengaruhnya Terhadap Sifat Tanah, Erosi dan Produktivitas Lahan. Disertasi. Program Pascasarjana Universitas Hasanuddin Makassar.

Jusuf, L. 2007. Pengaruh Dosis Pupuk Organik Padat Daun Gamal Terhadap Tanaman Sawi. Jurnal Agrisistem Vol. 3 No 2.

Kabar UKM. 2012. Meraup Untung di Lahan Kritis. Melalui www.kabarukm.com. diakses 5 November 2013.

Nurbaity, dkk. 2009. Pemanfaatan Bahan Organik Sebagai Bahan Pembawa Inokulan Fungi Mikoriza Arbuskula. Jurnal Biologi XIII (1) : 17- 11 ISSN : 1410 5292. Laboratorium Biologi dan Bioteknologi Tanah Fakultas Pertanian Universitas Padjadjaran.Bandung.

Rahayu, N. dan Ade K. A. 2003. Pemanfaatan Mikoriza dan Bahan organik Dalam Rangka Reklamasi Lahan Pasca Penambangan. Karya Tulis IImiah. Fakultas Pertanian Universitas Tanjungpura. Pontianak.

Simanungkalit, R D M. 2006. Pupuk Organik dan Pupuk Hayati. Balai Besar Litbang Sumberdaya Lahan Pertanian Badan Penelitian dan Pengembangan Pertanian. Bogor.

Utami, N. H. 2009. Kajian Sifat Fisik, Sifat Kimia dan Sifat Biologi Tanah Paska 
Tambang Galian C Pada Tiga Penutupan Lahan (Studi Kasus Pertambangan Pasir (Galian C) di Desa Gumulung Tonggoh, Kecamatan Astanajapura, Kabupaten Cirebon, Provinsi Jawa Barat). Departemen Silvikultur Fakultas Kehutanan Institut Pertanian Bogor. Bogor. 